\title{
Simulation of macauba palm cultivation: an energy-balance and greenhouse gas emissions analysis
}

Anderson Barbosa-Evaristo ${ }^{\mathrm{a}}$, Ignacio A. Fernández-Coppel ${ }^{\mathrm{b}}$, Adriana Corrêa-Guimarães ${ }^{\mathrm{c}}$, Jesús Martín-Gillc, Leonardo Duarte-Pimentel ${ }^{\mathrm{d}}$, José A. Saraiva-Grossi ${ }^{\mathrm{d}}$, Luis M. Navas-Gracia ${ }^{\mathrm{c}}$ and Pablo Martín-Ramose*

${ }^{a}$ Department of Agronomy, State University of Tocantins, TO 77020-122 Brazil; ${ }^{b}$ Engineering of Manufacturing Processes group, School of Industrial Engineering, University of Valladolid, C/ Francisco Mendizábal 1, 47014 Valladolid, Spain; ${ }^{c}$ Department of Agricultural and Forestry Engineering, ETSIIAA, University of Valladolid, Avenida de Madrid 44, 34004 Palencia, Spain; ${ }^{d}$ Department of Plant Sciences, Federal University of Viçosa, MG, 36570-900 Brazil; ${ }^{e}$ Department of Agricultural and Environmental Sciences, EPS, University of Zaragoza, Carretera de Cuarte s/n, 22071 Huesca, Spain.

Department of Agricultural and Environmental Sciences, EPS, University of Zaragoza, Carretera de Cuarte s/n, 22071 Huesca, Spain. E-mail: pmr@unizar.es; Tel: +34 (974) 292668; Fax: +34 (974) 239302 


\section{Simulation of macauba palm cultivation: an energy-balance and greenhouse gas emissions analysis}

The expansion of the production and use of bioenergy is deemed as one of the most efficient mechanisms to reduce greenhouse gas (GHG) emissions. Nevertheless, the environmental impact of the production processes for many raw materials remains unexplored. Several studies have pointed to macauba palm (Acrocomia aculeata (Jacq.) Lodd. ex Mart.) as a promising species for biofuel production in the tropics, but investigations on the environmental benefits of the cultivation of this palm as a source of raw material for biofuel production have not been reported so far. The aim of this work has been to conduct an analysis of macauba production system in terms of GHG emissions and $\mathrm{CO}_{2}$ uptake for a productive cycle, considering a 30-year horizon. The energy conversion efficiency (energy outputs/inputs ratio) per unit area of land has been put in relationship with crop productivity and related to the dilution effect of production inputs. Results of the simulation estimate that GHG emissions from macauba crop would be around 180 $\mathrm{Mg} \mathrm{CO} 2 \mathrm{eq} \cdot \mathrm{ha}^{-1}$, whereas $\mathrm{CO}_{2}$ fixation during cultivation would range from 796 to $1137 \mathrm{Mg} \mathrm{CO}_{2} \mathrm{eq} \cdot \mathrm{ha}^{-1}$. The energy assessment shows that the net energy balance for macauba crop would reach $512.3 \mathrm{GJ} \cdot \mathrm{ha}^{-1}$ and that the energy efficiency would be ca. $24.2 \mathrm{GJ} \cdot \mathrm{GJ}^{-1}$. These results, compared with those of traditional energy crops such as sugarcane, oil palm, sunflower, corn or jatropha, suggest that macauba crop may have the potential to outperform them in terms of efficiency. The domestication and exploitation in extensive farming of this species as an agroforestry crop, although still at an early stage, has a bright future.

Keywords: Acrocomia aculeata; greenhouse gas; life cycle analysis; macauba; primary energy

Subject classification codes: include these here if the journal requires them 


\section{Introduction}

Greenhouse gas emissions (GHG), which result in impacts on natural and human systems (IPCC 2014), are directly influenced by the type and amount of energy consumed in the world. World energy consumption is expected to increase from 575 quadrillion Btu in 2015 to 736 quadrillion Btu by 2040 (a 28\% increase) (U.S. Energy Information Administration 2017). Nowadays, collectively, all forms of renewable energy, including the traditional use of biomass, account for $14 \%$ of the global energy mix. According to the IEA (International Energy Agency 2016), in the 450 Scenario, modern renewables would account for $27 \%$ of the primary energy mix in 2040 and renewables would provide nearly $60 \%$ of power capacity additions in the New Policies Scenario (reaching 5170 GW in 2040), becoming the largest source of electricity supply before 2030 .

In spite of their inherent limitations (Pulles 2017), the growth in renewables-based capacity is expected to be based on wind, solar technologies and bioenergy. The latter has the potential to contribute to decarbonization of the power, heat and transport sectors, as well as bring wider benefits in terms of rural development and diversification of energy supply. However, it is important that these benefits are balanced against the sustainability considerations that are unique to each bioenergy supply chain application. An analysis of the emissions of each raw material and an assessment of its environmental impact throughout the whole process of fuel production are required.

When biofuels are produced from energy crops, the possible environmental benefits differ depending on parameters such as the chosen crop, the management system and the land use change (Fazio et al. 2014; Fargione et al. 2008; Monti et al. 2009). This has led to search for new multipurpose energy crops with high productivity, potential to be cultivated in marginal lands, low production costs, low environmental impact and 
which have not been traditionally used as a food source (Araújo et al. 2017; Delucchi 2010; Kline et al. 2017; Tomei et al. 2016).

In this regard, several studies have pointed to macauba palm (Acrocomia aculeata (Jacq.) Lodd. ex Mart.) as a promising species for biofuel production in the tropics due to its outstanding productivity, comparable to that of Elaeis guineensis Jacq., and its fruits' high oil content (Motoike et al. 2009; Ciconini et al. 2013; Nunes et al. 2015; César et al. 2015; Evaristo 2015; Evaristo, Grossi, Carneiro, et al. 2016; da Silva Lacerda, LópezSotelo, Correa-Guimarães, Hernández-Navarro, Sánchez-Báscones, et al. 2015; da Silva Lacerda, López-Sotelo, Correa-Guimarães, Hernández-Navarro, Sánchez-Bascones, et al. 2015; Plath et al. 2016). The macauba is a perennial, fruit-producing thorny arborescent palm tree, native to tropical forests. It is widely distributed throughout Central and South America, with the largest concentrations in Brazil (Henderson et al. 1997). Its natural occurrence is associated with areas of open vegetation and semideciduous and disturbed forests, being commonly found in anthropized areas with pasture or in association with crops (Scariot et al. 1991; Scariot et al. 1995; Falasca et al. 2016).

Some of the advantages reported for A. aculeata are (César et al. 2015; da Silva et al. 2017; Motoike and Kuki 2009; Pires et al. 2013): (i) this crop displays great potential to generate employment since its production is perennial for over 100 years; (ii) its productivity can reach $6 \mathrm{Mg}$ oil $\cdot \mathrm{ha}^{-1}$; (iii) it adapts to marginal soils and promotes the recovery of degraded areas through tree cover restoration; (iv) it is a disease-resistant palm tree and withstands large climate variations; $(v)$ with regards to sustainability, this crop enables intercropping and agroforestry systems (with forage and livestock production) (Ali et al. 2017); (vi) throughout its production cycle, it allows high $\mathrm{CO}_{2}$ absorption from the atmosphere, with a reduction of approximately $10 \mathrm{Mg} \cdot \mathrm{ha}^{-1}$ of $\mathrm{CO}_{2}$ for each hectare planted (Silva 2007); (vii) there are good market opportunities for its oil, 
which is not commonly used for food purposes due to its high acid index -so it does not result in competition with food sources-; (viii) its cultivation is a profitable activity for farmers (da Silva et al. 2017), even considering a cultivation period of 20 years.

To the best of the authors' knowledge, environmental analyses on the cultivation of macauba have not been reported in the literature, but would be of great importance to subsidize the use of this palm for biodiesel production. This study presents a simulation of macauba cultivation, based on literature databases and data from young macauba plantations, with a view to assess its potential for bioenergy production and to estimate GHG emissions and $\mathrm{CO}_{2}$ capture associated to its cultivation, providing an educated guess of its energy conversion efficiency along a productive cycle, with a 30-year horizon.

\section{Material and methods}

\section{Scope, limits and functional unit of the study}

This simulation case focused on the agricultural subsystem for the production of biomass for energy purposes, covering the land preparation and maintenance, planting, crop management and harvesting stages (see Figure 1). The system boundaries included the production of raw materials, fuels and agricultural machinery, the supply of inputs, the implementation, management and harvesting of fresh bunches (FB) of macauba palm over a 30-year cultivation period and the transportation of fresh bunches to the farm gate. A ‘cradle-to-farm gate’ life cycle assessment (LCA) approach was considered. Fruit transportation to the processing unit, its storage and preservative treatments, oil extraction and conversion to biodiesel processes (industrial phase) were not included in the analysis, given the absence of a well-established 'mainstream' procedure for the latter.

The chosen functional unit for the agricultural subsystem was the megagram (Mg) of fresh bunch of macauba per hectare per year $\left(\mathrm{Mg} \mathrm{FB} \cdot \mathrm{ha}^{-1} \cdot \mathrm{y}^{-1}\right)$, and the impact 
categories analyzed in this work were referred to: (1) the energy balance, expressed in Joules per hectare per year $\left(\mathrm{J} \cdot \mathrm{ha}^{-1} \cdot \mathrm{y}^{-1}\right)$; and (2) to GHG emissions, measured in $\mathrm{Mg}$ $\mathrm{CO}_{2} \mathrm{eq} \cdot \mathrm{ha}^{-1} \cdot \mathrm{y}^{-1}$, provided that these are the most often impact categories in biofuel LCAs (Shonnard et al. 2015). All the presented results are average values referring to the 30year macauba cultivation period.

\section{Site characterization and data collection}

At the time of this study (2015), there were only two commercial plantations of macauba palm in the Minas Gerais (Brazil) region: an 8-year-old one (property of Entaban Ecoenergéticas do Brasil Ltda. (Lima Duarte, MG, Brazil)) and a 2-year-old one (property of Acrotech Ltda. (Viçosa, MG, Brazil)) both with a planting density of 460 plants $\cdot$ ha $^{-1}$. Since the former had been abandoned, only data from the Acrotech Ltda. plantation was used to characterize the inputs of the crop in terms of soil preparation, cuttings, selection and rooting, planting, cultivation, phytosanitary treatments, fertilization, harvest, etc. and early care of the agroforestry exploitation.

Fruit production data were obtained from a native (i.e., not human-cultivated) population of macauba palm trees, growing in a pasture area (Brachiaria decumbes). The area around $16^{\circ} 29^{\prime} 54.90^{\prime \prime} \mathrm{S}, 44^{\circ} 4^{\prime} 12.43^{\prime \prime} \mathrm{W}$ coordinates, with an altitude of $c a .818 \mathrm{~m}$, had a gently rolling topography, representative of the northern region of Minas Gerais, Brazil (IBGE 2006).

The chosen region belongs to the Cerrado biome, a neotropical savannah that includes parts of eleven Brazilian federal states and extends from the Equator to the Tropic of Capricorn. According to Köppen classification, the Cerrado exhibits a typical Aw climate (humid tropical savannah) with a distinct dry season between May and September. The average annual precipitation is 1,200 mm (Antunes 1986; Ramos et al. 2009). 


\section{Description of macauba palm fruits}

Macauba palm usually emits four-six bunches per year (12-15 kg each) (Manfio et al. 2011), containing 150-500 fruits of the drupe type. These fruits are composed of a chartaceous epicarp (husk); a thin, mucilaginous, and fibrous mesocarp (pulp); and a hard and dense endocarp, which contains the seed (almond) adhered to the endocarp (Scariot et al. 1995; Reis et al. 2012). All fruit components present interesting features for bioenergy production: the husk has a high calorific value (20.24 $\mathrm{MJ} \mathrm{kg}^{-1}$ ) (Evaristo, Grossi, Carneiro, et al. 2016; Evaristo, Martino, et al. 2016); the pulp has a high oil content (45 to 58\%), with a high concentration of unsaturated fatty acids -in particular oleic acid (18:1)- and a low content in free fatty acids when the fruits are harvested directly from the bunches (Evaristo, Grossi, Pimentel, et al. 2016; del Río et al. 2016); the endocarp has a high calorific value (20.45 $\mathrm{MJ} \mathrm{kg}^{-1}$ ) and is rich in lignins (Evaristo, Grossi, Carneiro, et al. 2016; Evaristo, Martino, et al. 2016); and the kernel is rich in oil (61-63\%), with a high concentration of short-chain saturated fatty acids (del Río et al. 2016). However, genetic diversity is known to lead to large variations in the physical characteristics and oil yield, affecting parameters such as the oil percentage in mesocarp, the types of fatty acids in the mesocarp and kernel, or the weight of the whole fruit (da Conceição et al. 2015).

\section{Analysis of the plant material}

A random sampling from 100 native macauba specimens in a pasture area was conducted (Figure $2(a)$ and $(b)$ ), in agreement with the procedure described by Evaristo, Grossi, Carneiro, et al. (2016), out of which 20 were used for the quantification of the constituent parts of the fruit (husk, pulp, endocarp and almond), fresh weight, dry weight and moisture content of each constituent part of the bunches and fruits. Moisture contents were determined by drying the samples at $105{ }^{\circ} \mathrm{C}$ until constant mass was reached, 
according to ISO 18134-3:2015 methodology (ISO 2015).

As noted above, this random sampling had to be conducted on native plants, provided that in the only operative extensive macauba plantation in the region the palm trees were still in their early stage of growth and were yet to enter their productive years.

Samples from the constituent parts of fruits and empty fruit bunches (EFB) were taken to determine the chemical composition ( $\mathrm{CHN})$, the net caloric value (NCV) and the oil content in the pulp and kernel. The oil content in pulp and kernel was quantified by nuclear magnetic resonance (NMR) with a Benchtop NMR MQC analyzer (Oxford Instruments, Abingdon, UK) following the method proposed by ISO (ISO 1995). For the other analyses, the samples were dried, ground in a Thomas Wiley stainless steel mill (Thomas Scientific, Swedesboro, NJ, USA) and sieved with two overlapping screens (200 mesh and 270 mesh), using for the assays the fraction retained in the latter.

The determination of the chemical composition was done in accordance with the methodology described by CEN/TS 15104, using a 2400 Series II CHNS/O elemental analyzer (Perkin Elmer, Waltham, MA, USA).

As a prior step to the determination of the NCV of the fruit, of its constituent parts and of EFB, the higher caloric value (HCV) of all the constituent parts of the plant was determined according to the methodology described in the standard ASTM D 2015-77 (ASTM 1996), using an Fisher Scientific (Hampton, NH, USA) adiabatic bomb calorimeter. To determine the higher caloric value of the whole fruit, $\mathrm{HCV}_{\text {fruit, }}$ the following formula was used:

$$
\begin{aligned}
& \mathrm{HCV}_{\text {fruit }}=\left(\mathrm{HCV}_{\text {epicarp }} \times \mathrm{PWF}_{\text {epicarp }}\right)+\left(\mathrm{HCV}_{\text {pulp bran }} \times \mathrm{PWF}_{\text {pulp bran }}+\right. \\
& \left.\mathrm{HCV}_{\text {pulp oil }} \times \mathrm{M}_{\text {pulp oil }}\right)+\left(\mathrm{HCV}_{\text {endocarp }} \times \mathrm{PWF}_{\text {endocarp }}\right)+\left(\mathrm{HCV}_{\text {kernel bran }} \times\right. \\
& \left.\mathrm{PWF}_{\text {kernel bran }}+\mathrm{HCV}_{\text {kernel oil }} \times \mathrm{M}_{\text {kernel oil }}\right)
\end{aligned}
$$


in which

- $\quad \mathrm{HCV}=$ higher calorific value $\left(\mathrm{MJ} \cdot \mathrm{kg}^{-1}\right)$

- $\quad \mathrm{PWF}=$ proportion of waste generated in relation to the fruit $\left(\mathrm{kg} \cdot \mathrm{kg}^{-1}\right)$.

- $\quad \mathrm{M}_{\text {pulp oil }}=$ mass of pulp oil contained in the fruit $(\mathrm{kg})$

- $\quad$ Mkernel oil $=$ mass of kernel oil contained in the fruit $(\mathrm{kg})$

PWF was calculated as the proportion of mass (dry matter) of each fruit waste relative to the whole fruit mass (dry matter), according to the equation: PWF = $\mathrm{M}_{\text {waste }} / \mathrm{M}_{\text {fruit }}$, in which $\mathrm{M}_{\text {waste }}$ is the mass of the residue (e.g., husk) and $\mathrm{M}_{\text {fruit }}$ is the mass of the fruit.

The NCV of the fruit residues (the metric used in the rest of the document, to allow direct comparison to all fuels defined in the IPCC guidelines and IEA energy stats) was calculated according to the following equation, considering $0.1 \mathrm{~kg} \cdot \mathrm{kg}^{-1}$ moisture for all residues:

$$
\mathrm{NCV}=[(\mathrm{HCV}-\gamma(\mathrm{W}+9 \mathrm{H}))(1-\mathrm{W})]
$$

where

- $\quad \mathrm{NCV}=$ net caloric value $\left(\mathrm{MJ} \cdot \mathrm{kg}^{-1}\right)$

- $\quad \mathrm{HCV}=$ higher caloric value $\left(\mathrm{MJ} \cdot \mathrm{g}^{-1}\right)$

- $\gamma=$ latent heat of water $=2.31 \mathrm{MJ} \cdot \mathrm{kg}^{-1}$ at $25^{\circ} \mathrm{C}$

- $\mathrm{H}=$ hydrogen content $\left(\mathrm{kg} \cdot \mathrm{kg}^{-1}\right)$

- $\mathrm{W}=$ sample moisture content $\left(\mathrm{kg} \cdot \mathrm{kg}^{-1}\right)$, that is, the average hygroscopic moisture under equilibrium for this particular biomass. 


\section{Inventory and scenarios}

Table 1 summarizes the operating yield of the agricultural machinery, human activities and inputs used for the cultivation of macauba palm over a 30-year cultivation period. The data were primarily obtained from the Acrotech Ltda. commercial plantation mentioned above or from scientific publications (Pimentel et al. 2011b; Motoike et al. 2013; Pimentel et al. 2011a), but in some cases they had to be extrapolated from analogous crops (viz., coconut palm trees and oil palm trees), in which the Universidade Federal de Viçosa and Acrotech Ltda. have extensive experience.

The fresh bunches production was estimated on the basis on the assessment of 100 adult native palm trees in the study area, close to the commercial plantation. The number of bunches per plant, number of fruits per bunch and average weight of both bunches and fruits were quantified by weighing the native macauba palm fruits and counting the number of bunches per native palm (Figure 2).

To estimate the productivity, three simulation scenarios were proposed (Table 2) on the basis of the data collected from the native plants, taking a plant selection criteria based on the number of bunches per plant (NBP). Scenario S1 considers the average productivity for all the native plants; scenario S2 would correspond to the average productivity for the plants above percentile 50 (P50) in terms of NPB; and scenario S3 would correspond to the productivity of the best 30\% of the plants (above P70 in terms of NPB). For all scenarios, the values were expressed in megagrams of fresh bunches (FB) per hectare, considering a density of 461 plants per hectare, with a $5 \mathrm{~m} \times 5 \mathrm{~m}$ equilateral triangle spacing (21.65 $\mathrm{m}^{2} / \mathrm{palm}$ tree), following the recommendations of Motoike et al. (2013). The productivity in the first years (until the adult phase), in percentage terms, was estimated taking as a reference the evolution of the productivity of 
oil palm (Elaeis guineenses) (Corley et al. 2015), adjusting the fruit production according to the average number of fruits per bunch in macauba palm.

\section{Crop energy balance}

The use of machinery, raw materials and labor were estimated taking into consideration the cultivation site and technical coefficients data. The flow of incoming and outgoing materials for agricultural production was converted to equivalent energy and evaluated as cumulative energy demand (CED) and gross energy (GE).

The equivalent energy inputs, or energy consumed for agricultural production, are shown in Table 3.

The energy used for mechanized operations was calculated according to fuel consumption and the amount of greases and lubricant required for each mechanized operation, multiplied by their respective equivalent energies. The energy used in the manufacturing of tractors and implements was estimated using the energy depreciation methodology (Doering et al. 1977).

The energetic calculation of cuttings production was conducted using data provided by Acrotech Ltda., which was converted to energy using the equivalent factors presented in Table 3.

Energy spending in relation to the transportation of production inputs (cuttings, fertilizers and agrochemicals) was estimated considering the consumption of fuels, greases and lubricants for road transport, according to load capacity and truck models used in Brazil (Ministério do Meio Ambiente 2011). For the transportation of the macauba cuttings, a load capacity of $10 \mathrm{t}$ per truck and a distance of $710 \mathrm{~km}$ from the greenhouse where the cuttings are produced to the cultivation area were considered. The transport of fertilizers involved a truck with a 20 t load capacity and distances of $116 \mathrm{~km}$ and $490 \mathrm{~km}$ to transport limestone and fertilizer, respectively (distance from the nearest plants in the 
cultivation area). In relation to agrochemicals, the capacity of truck and travel distance were $10 \mathrm{t}$ and $70 \mathrm{~km}$, respectively. The fuel mixture for tractors and trucks was 95\% diesel and 5\% biodiesel, according to the federal law of Brazil enforced in 2015.

Quantification of gross energy (GE) was calculated using the formula below:

$$
\mathrm{GE}_{\text {bunches }}=\left(\mathrm{NCV}_{\text {fruits }} \times \mathrm{P}_{\text {fruits }}\right)+\left(\mathrm{NCV}_{\mathrm{EFB}} \times \mathrm{P}_{\mathrm{EFB}}\right)
$$

where GE is the gross energy $\left(\mathrm{GJ} \cdot \mathrm{ha}^{-1}\right), \mathrm{NCV}_{\text {fruits }}$ is the net caloric value of the fruits $\left(\mathrm{GJ} \cdot \mathrm{Mg}^{-1}\right), \mathrm{NCV}_{\mathrm{EFB}}$ is the net caloric value of the empty fruit bunches $\left(\mathrm{GJ} \cdot \mathrm{Mg}^{-1}\right), \mathrm{P}_{\text {fruits }}$ is the productivity of fruits $\left(\mathrm{Mg} \cdot \mathrm{ha}^{-1}\right)$ and $\mathrm{P}_{\mathrm{EFB}}$ is the productivity of EFB $\left(\mathrm{Mg} \cdot \mathrm{ha}^{-1}\right)$.

Based on CED and GE, two different indicators were used for energy assessment: net energy (NE) and energy efficiency (EE), which were calculated according to the following formulas:

$$
\begin{array}{ll}
\mathrm{NE}=\mathrm{GE}-\mathrm{CED} & \text { Eq. (4) } \\
\mathrm{EE}=\mathrm{GE} / \mathrm{CED} & \text { Eq. (5) }
\end{array}
$$

\section{Inventory of greenhouse gas (GHG) emissions}

Based on the technical crop coefficients and inputs used, the GHG emissions were estimated and converted to $\mathrm{CO}_{2}$ in global warming potential units (GWPs) (Intergovernmental Panel on Climate Change (IPCC) 2006). The estimation of the GHG emissions over the 30-year cultivation period considered in this simulation included the changes in land use, mechanized operations, supply of inputs, application and production of fertilizers, production of pesticides and fossil fuels (diesel), soil management and indirect emissions from fertilizers.

GHG emissions due to changes in land use were put in relation to the conversion of grasslands into a perennial crop (macauba palm) (Colombo et al. 2017; Plath et al. 
2016; César et al. 2015), in line with the need for restoration of degraded areas in the Cerrado biome (which would correspond to $60 \%$ of the pastures in this biome, over 32 million hectares, according to EMBRAPA (Bayma 2014)). A stored carbon debit in the soil for five years, based on the patterns of land use change values in the country, was considered (British Standards Institution 2011).

GHG emissions from supply inputs and mechanized cropping practices were estimated on the basis of the consumption of diesel for each activity multiplied by the GHG emissions, in agreement with PAS 2050 (British Standards Institution 2011) and IPCC protocols (Intergovernmental Panel on Climate Change (IPCC) 2006; Ministério do Meio Ambiente 2011). Emissions from diesel production were determined according to Vianna (2006), using specific data of GHG emissions for diesel production in Brazil.

Direct and indirect emissions of GHG for soil management, application of fertilizers and limestone were calculated according IPCC protocol (Intergovernmental Panel on Climate Change (IPCC) 2006). The GHG emitted during the production of agricultural inputs (pesticides, herbicides, nitrogen-based fertilizers, potassium and phosphorus) were calculated by multiplying the amount used by the coefficients suggested by Macedo et al. (2008) and by UNFCCC (2010).

The $\mathrm{CO}_{2}$ fixed in the macauba crop was estimated according to Tolêdo (2010), who determined the carbon stock for various components (stipe, leaves and roots) of native adult plants of macauba of unknown age. Carbon content in bunches (fruits and EFB) was calculated in agreement with CEN/TS 15104 methodology (European Committee for Standardization (CEN) 2006). Subsequently, the carbon content was multiplied by the productivity of bunches and the conversion of carbon to $\mathrm{CO}_{2}(44 / 12)$ was made. 


\section{Results and discussion}

\section{Agricultural productivity}

Table 4 shows the estimated yield of fresh bunches for the macauba palm exploitation over 30 years, together with data corresponding to the dry matter yield and the carbon and oil contents in the constituent parts of the fruit. The fruits represented $95 \%$ of the bunches dry matter. The pulp was the most representative constituent of the fruit (46.8\%) and accounted for $46.27 \%$ of the bunches dry matter (Table 4). The oil percentage in the bunches was $45.5 \%\left(0.455 \mathrm{~g} \cdot \mathrm{g}^{-1}\right)$, which can be deemed as high: $1 \mathrm{Mg}$ of dry matter of bunches would produce $235.3 \mathrm{~kg}$ of oil $(203.05 \mathrm{~kg}$ from the pulp and the rest from the kernel). The endocarp was the constituent with the highest percentage of carbon, followed by husk, EFB and almond (Reis et al. 2012; Coimbra et al. 2011). The high carbon content in the endocarp and husk can be ascribed to their constitution and function: the husk, as the protective layer of the fruit, suffers sclerification and lignification when the fruit is ripe; and the endocarp, the layer that protects the almond, is a compact and rigid structure (due the high degree of lignification of the sclereids) (Reis et al. 2012).

Fruit yield grew over the years in all the predicted scenarios (Table 4). As plants with the highest number of bunches per plant are selected, productivity would substantially increase, achieving an average yield of $48.3 \mathrm{Mg} \mathrm{FB} \cdot \mathrm{ha}^{-1} \cdot \mathrm{y}^{-1}$ in S3 (10\% of the plants with the largest bunch numbers of a native population) after a 10-year cultivation period. Studies show that the number of bunches per plant parameter has high heritability and low environmental influence (Lopes et al. 2012; Gomes Jr et al. 2014). In this regard, when plants that have large numbers of bunches are selected, they tend to generate progenies with high number of bunches per plant too. Untamed plants or those under a domestication process, such as macauba, show high genetic variability and the initial gains through plant improvement tend to be high at the beginning of the breeding 
program. Consequently, the base population choice and the mother plant selection methods for the cuttings would be decisive as regards the increase in fruit productivity of the macauba crop over the years (Berton et al. 2013; Coser et al. 2016; Montoya et al. 2016; Castro et al. 2017).

\section{Energy balance of the crop}

Estimates of CED and GE over the 30-year cultivation period in the different fruit productivity scenarios are presented in Figure 3.

The average energy consumption over the years in different scenarios ranged from $20.9 \mathrm{GJ} \cdot \mathrm{ha}^{-1} \cdot \mathrm{y}^{-1}$ to $22.1 \mathrm{GJ} \cdot \mathrm{ha}^{-1} \cdot \mathrm{y}^{-1}$, for scenarios 1 and 3, respectively. In all scenarios, the highest and the lowest energy consumption corresponded to the production of fertilizers and pesticides and the production of machinery and implements, with 17.85 $\mathrm{GJ} \cdot \mathrm{ha}^{-1} \cdot \mathrm{y}^{-1}$ and $0.0791 \mathrm{GJ} \cdot \mathrm{ha}^{-1} \cdot \mathrm{y}^{-1}$, respectively. This can be readily explained by the fact that the crop management was the same for all scenarios, with no difference in the use of inputs such as pesticides and fertilizers.

Fuel consumption was the second largest contributor to the CED, ranging from 3.55 GJ $\cdot \mathrm{ha}^{-1} \cdot \mathrm{y}^{-1}$ in S1 to $3.63 \mathrm{GJ} \cdot \mathrm{ha}^{-1} \cdot \mathrm{y}^{-1}$ in S3. This variation among scenarios arises from the increased bunches productivity, which would lead to higher fuel consumption in their harvesting and transportation. The parameter that registered the highest increase among the scenarios was the energy spent in human activities, which was 32\% higher in S3 than in S1. In a similar fashion to fuel consumption, the harvest operation would require more labor due the increase in productivity between the scenarios.

As regards to the total GE (fruits+EFB), the differences among scenarios were highly significant: in S3, a value of $534.4 \mathrm{GJ} \cdot \mathrm{ha}^{-1} \cdot \mathrm{y}^{-1}$ was reached, with an increase of approximately $170 \%$ in comparison with S1 (Figure 3). The fruits contributed to ca. $96 \%$ of the GE for all scenarios. This high increase in GE would be due to the increase in 
calorific productivity of the EFB and the high energy of the fruit components (vegetable oils have high calorific values, close to those of fossil fuels like diesel) (Ramadhas et al. 2004). In macauba bunches (fruits and EFB), 23.5\% was pulp oil and kernel oil (Table 4). The endocarp constituted around $20 \%$ of the dry matter of the bunch, and its quite dense and lignified structure also introduced high calorific energy (Reis et al. 2012; Vilas Boas et al. 2010).

The estimate of the energy assessment (NE and EE) of macauba cultivation for the proposed scenarios showed that this species has a great potential as an energy crop for Tropical regions (Table 5). In S1, NE and SE already suggest that macauba would be more efficient than annual crops such as sunflower, corn or the castor oil plant (Table 5). By increasing the productive potential of plants (scenario S2), macauba cultivation would become more energy efficient than perennial species such as Jatropha curcas L. (Table 5). For the most productive scenario, S3, the EE efficiency in the cultivation of macauba palm would even approach that of Elaeis guineensis palm, the most cultivated oil-bearing species in the world. In spite of the fact that it would be hard for a new and undeveloped crop to achieve the same performance as the advanced Elaeis guineensis hybrids, these values can be explained by the higher number of macauba plants per unit area (461 plants $\cdot \mathrm{ha}^{-1}$ ) as compared to the African oil palm (with planting densities of ca. 120 plants $\cdot \mathrm{ha}^{-1}$ in Brazil), resulting from differences in the layout and angulation of leaves between these two palm species, which allow macauba to have more plants per unit area. Furthermore, macauba fruits have a much larger and dense endocarp than that of African oil palm and a fibrous shell, and these two fruit constituents contribute to the higher energy content of macauba fruits, provided that they have high contents of lignin (Evaristo, Grossi, Carneiro, et al. 2016) and they are suitable for the production of biofuels such as charcoal (Evaristo, Martino, et al. 2016). 
In relation to CED, macauba cultivation would attain the second highest value of all energy crops, after corn. It is also worth noting that the cultivation of this palm tree proves to be highly dependent on raw materials and fuels (Table 1, Figure 3), which caused a high CED for all scenarios. However, the increase in CED was small when the productivity of macauba was increased (Table 5, Figure 3).

\section{$\mathrm{CO}_{2}$ eq balance}

Estimates of GHG emissions and carbon sequestration by macauba palm tree during its cultivation for the proposed scenarios are presented in Figure 4. In all scenarios, the GHG emissions were similar, with only a very slight increase of about $1 \%$ from S1 to S3, reaching $181.45 \mathrm{Mg} \mathrm{CO} \mathrm{eq} \mathrm{ha}^{-1}$ in 30 years. Crop management was responsible for most of these GHG emissions (94 $\mathrm{Mg} \mathrm{CO} 2 \mathrm{eq} \cdot \mathrm{ha}^{-1}$ in 30 years), and the direct and indirect $\mathrm{N}_{2} \mathrm{O}$ emissions associated to the use of urea and lime were the main emitters in this stage. In fact, Monti et al. (2009) showed that for four perennial energy crops (viz., giant miscanthus (Miscanthus $\times$ giganteus), giant cane (Arundo donax L.), switchgrass (Panicum virgatum L.) and cardoon (Cynara cardunculus L.)) the greatest impact on GHG emissions came from the use of fertilizers.

Another important component in terms of its contribution to GHG emissions was the land use change (LUC), from pasture to a perennial species, which represented 42.5 $\mathrm{Mg} \mathrm{CO} 2 \mathrm{eq} \cdot \mathrm{ha}^{-1}$ in all scenarios. This value results from a quantification of the GHG emissions arising from a change from grassland to perennial cropland in Brazil (default LUC value of $8.5 \mathrm{Mg} \mathrm{CO} 2 \mathrm{eq} \cdot \mathrm{ha}^{-1} \cdot \mathrm{yr}^{-1}$ in a 5 -year period) (British Standards Institution 2011). GHG emissions due to LUC can greatly vary depending on the original vegetation present before the ground change. For instance, larger GHG emissions would occur if a conversion from forest land to perennial cropland took place (26 Mg CO $\left.2 \mathrm{eq} \cdot \mathrm{ha}^{-1} \cdot \mathrm{yr}^{-1}\right)$. However, in comparison, for the conversion from pasture -mainly degraded- emissions 
would be significantly lower, and there may be gains in soil carbon (Fargione et al. 2008; Germer et al. 2007). In fact, in a recent EU-funded 2.7 M€ INOCAS research project it has been claimed that the silvipastoral system resulting from the implantation of the macauba plantation would involve no LUC (Averdunk et al. 2012). Thus, the analysis presented herein may be regarded as a conservative GHG balance estimation.

Agricultural machinery use and transport of agricultural supplies and fruit bunches inside the plantation were the factors that accounted for the variation among scenarios: in the most productive scenarios, there was an increase in GHG emissions because of the higher diesel consumption in the harvesting and transportation of the additional bunches. The increase between S1 and S3 scenarios was ca. 32\% (1.75 Mg $\mathrm{CO}_{2} \mathrm{eq} \cdot \mathrm{ha}^{-1}$ ) due to agricultural machinery use. Apropos of the transport of agricultural supplies and fruit bunches inside the plantation, it only increased by ca. $11 \%(0.18 \mathrm{Mg}$ $\mathrm{CO}_{2} \mathrm{eq} \cdot \mathrm{ha}^{-1}$ in 30 years) between S1 and S3 scenarios. This relatively small increase in GHG emissions, which is not proportional to the productivity increase across scenarios, can be ascribed to the fact that a lot of manual labor is involved in the harvesting operations.

The raw material choice for the biofuel production also has a direct impact on the amount of emitted GHGs, so the use of biofuels would promote environmental benefits. Studies on life cycle analysis of biofuels obtained from energy crops show that most of the GHG emissions and other environmental impacts are due to the agricultural activities (Hansen 2005; Fazio et al. 2011). Li et al. (2014) reported that GHG emissions related to the production of camelina oil (Camelina sativa L. Crantz) for biodiesel production varied from $66.5 \%$ to $70.3 \%$ depending on the scenario. González-García et al. (2012) reported that $78 \%$ of GHG emissions associated with biodiesel production from rapeseed were due to the agricultural stage. 
On the other hand, apart from GHG emissions, it is important -from an environmental point of view- to choose raw materials that have high $\mathrm{CO}_{2}$ fixation rates. In this regard, in the cultivation of macauba, bunches are responsible for most of the $\mathrm{CO}_{2}$ fixation, representing up to $71 \%$ of the $\mathrm{CO}_{2}$ fixed by the plants in S3 scenario (Figure 4). When the presumable increase in bunch productivity was considered, total $\mathrm{CO}_{2}$ fixation (biogenic $\mathrm{CO}_{2}$ fixed by the crop in the palm trees + bunches) reached up to $1.14 \mathrm{Gg}$ $\mathrm{CO}_{2} \mathrm{eq} \cdot \mathrm{ha}^{-1}$ in 30 years for $\mathrm{S} 3 . \mathrm{CO}_{2}$ fixation captured during the growth of palm trees (excluding bunches) was estimated at $10.96 \mathrm{Mg} \mathrm{CO} 2 \mathrm{eq} \cdot \mathrm{ha}^{-1} \cdot \mathrm{y}^{-1}$, out of which belowground biomass accounted for ca. $2.63 \mathrm{Mg} \mathrm{CO} 2 \mathrm{eq} \cdot \mathrm{ha}^{-1} \cdot \mathrm{y}^{-1}$, according to the 0.24 shootto-root ratio proposed by (Tolêdo 2010), based on IPCC data. The $\mathrm{CO}_{2} \mathrm{eq}$ emissions balance for the macauba plantation ranged from $-617 \mathrm{Mg} \mathrm{CO}_{2} \mathrm{eq} \cdot \mathrm{ha}^{-1}$ in $\mathrm{S} 1$ to $-956 \mathrm{Mg}$ $\mathrm{CO}_{2} \mathrm{eq} \cdot \mathrm{ha}^{-1}$ in S3. These values evince the great potential of this species in the mitigation of climate effects. Germer and Sauerborn (2007) estimated that the GHG balance in the oil palm cultivation ranged from $-136( \pm 37) \mathrm{Mg} \mathrm{CO}_{2} \mathrm{eq} \cdot \mathrm{ha}^{-1}$ to $1,335( \pm 690) \mathrm{Mg} \mathrm{CO}_{2} \mathrm{eq} \cdot \mathrm{ha}^{-}$

${ }^{1}$ depending on management and changes in land use. The comparatively larger amount of $\mathrm{CO}_{2} \mathrm{eq}$ that would be fixed in the cultivation of macauba palm would be due to its higher yield in fruits (Motoike and Kuki 2009; Evaristo 2015), the composition and weight of the fruits (Evaristo 2015) and the planting density of this species (as noted above, in this study, a planting density of 460 plants ha $^{-1}$-usual in commercial plantations- was considered (Motoike et al. 2013), which is about three times higher than that recommended for the cultivation of palm oil (Corley and Tinker 2015)).

\section{Conclusions}

Macauba palm has been posed as a promising energy crop in tropical regions provided that it can be a suitable raw material for the production of various solid, liquid and gaseous biofuels. The simulation presented in this study, based on the defined boundary 
conditions, has assessed the potential of macauba palm for bioenergy production in terms of energy balance and greenhouse gas emissions. When plants with larger numbers of bunches were selected, macauba cultivation presented very high energy efficiencies that could exceed those of conventional energy crops (e.g., those of sunflower, corn, castor oil plant, Jatropha curcas L.) and would be second after Elaeis guineensis palm in the most productive scenario (S3). GHG emissions varied in small amounts amongst the different proposed scenarios, but $\mathrm{CO}_{2}$ fixation clearly increased as a result of productivity increases. The $\mathrm{CO}_{2} \mathrm{eq}$ emissions balance ranged from $-617 \mathrm{Mg} \mathrm{CO}$ eq $\cdot \mathrm{ha}^{-1}$ in the least productive scenario (S1) to $-956 \mathrm{Mg} \mathrm{CO} 2 \mathrm{eq} \cdot \mathrm{ha}^{-1}$ in the most productive one (S3). Consequently, the domestication and genetic improvement of this species by selection methods -aimed at increasing bunch productivity- holds great promise and can substantially increase environmental (and economical) benefits. Further LCA analyses on other environmental aspects and on the industrial phase are underway.

\section{References}

Ali, B. M., P. B. M. Berentsen, J. W. M. Bastiaansen, and A. Oude Lansink. 2017. "A stochastic bio-economic pig farm model to assess the impact of innovations on farm performance." Animal 12:1-12. doi: 10.1017/s1751731117002531.

Antunes, F. Z. 1986. "Caracterização climática do estado de Minas Gerais." Informe Agropecuário 12 (139):9-13.

Araújo, Kathleen, Devinder Mahajan, Ryan Kerr, and Marcelo da Silva. 2017. "Global biofuels at the crossroads: An overview of technical, policy, and investment complexities in the sustainability of biofuel development." Agriculture 7 (4):32. doi: 10.3390/agriculture7040032. 
ASTM. 1996. "ASTM D2015: Standard Method for Gross Calorific Value of Solid Fuel by the Adiabatic Bomb Calorimeter." In. West Conshohocken, PA, USA: American Society for Testing and Materials.

Averdunk, Katharina, Thilo Zelt, Philipp Golka, Malte Höpfner, Corina Müller, and Ilka Bettermann. 2012. "Macauba - Sustainable palm oil results of the feasibility study of the Leuphana University of Lüneburg. Executive summary." In, 9. Lüneburg, Germany: University of Lüneburg.

Bayma, Gustavo "Embrapa mapeia degradação das pastagens do Cerrado." Embrapa, Accessed December 5, 2017. https://www.embrapa.br/busca-de-noticias//noticia/2361250/embrapa-mapeia-degradacao-das-pastagens-do-cerrado.

Berton, Luiz Henrique Chorfi, Joaquim Adelino de Azevedo Filho, Walter José Siqueira, and Carlos Augusto Colombo. 2013. "Seed germination and estimates of genetic parameters of promising macaw palm (Acrocomia aculeata) progenies for biofuel production." Industrial Crops and Products 51:258-66. doi: 10.1016/j.indcrop.2013.09.012.

British Standards Institution. 2011. PAS 2050:2011, Specification for the assessment of the life cycle greenhouse gas emissions of goods and services. London, UK: BSI, UK Department for Environment Food \& Rural Affairs, UK Department of Energy \& Climate Change and UK Department for Business Innovation \& Skills.

Castro, Carla Aparecida de O., Rafael T. Resende, Kacilda N. Kuki, Vinícius Q. Carneiro, Gustavo E. Marcatti, Cosme Damião Cruz, and Sérgio Y. Motoike. 2017. "Highperformance prediction of macauba fruit biomass for agricultural and industrial purposes using Artificial Neural Networks." Industrial Crops and Products 108:806-13. doi: 10.1016/j.indcrop.2017.07.031. 
César, Aldara da Silva, Fabiano de Azedias Almeida, Raquel Pereira de Souza, Gilmar Clemente Silva, and A. E. Atabani. 2015. "The prospects of using Acrocomia aculeata (macaúba) a non-edible biodiesel feedstock in Brazil." Renewable and Sustainable Energy Reviews 49:1213-20. doi: 10.1016/j.rser.2015.04.125.

Ciconini, Gabrielly, S. P. Favaro, R. Roscoe, C. H. B. Miranda, C. F. Tapeti, M. A. M. Miyahira, L. Bearari, et al. 2013. "Biometry and oil contents of Acrocomia aculeata fruits from the Cerrados and Pantanal biomes in Mato Grosso do Sul, Brazil." Industrial Crops and Products 45:208-14. doi: 10.1016/j.indcrop.2012.12.008.

Coimbra, Michelle Cardoso, and Neuza Jorge. 2011. "Characterization of the Pulp and Kernel Oils from Syagrus oleracea, Syagrus romanzoffiana, and Acrocomia aculeata." Journal of Food Science 76 (8):C1156-C61. doi: 10.1111/j.17503841.2011.02358.x.

Colombo, Carlos Augusto, Luiz Henrique Chorfi Berton, Brenda Gabriela Diaz, and Roseli Aparecida Ferrari. 2017. "Macauba: a promising tropical palm for the production of vegetable oil." Oilseeds and fats, Crops and Lipids (['The oil \& protein crop supply chain in South America' Special issue]):1-9. doi: 10.1051/ocl/2017038.

Corley, R. H. V., and P. B. H. Tinker. 2015. The oil palm. 5th ed. Hoboken, NJ, USA: Wiley-Blackwell.

Coser, S. M., S. Y. Motoike, T. R. Corrêa, T. P. Pires, and M. D. V. Resende. 2016. "Breeding of Acrocomia aculeata using genetic diversity parameters and correlations to select accessions based on vegetative, phenological, and reproductive characteristics." Genetics and Molecular Research 15 (4). doi: 10.4238/gmr15048820. 
da Conceição, Léo Duc Haa Carson Schwartzhaupt, Rosemar Antoniassi, Nilton Tadeu Vilela Junqueira, Marcelo Fideles Braga, Adelia Ferreira de Faria-Machado, Joice Barbosa Rogério, Iara Duprat Duarte, and Humberto Ribeiro Bizzo. 2015. "Genetic diversity of macauba from natural populations of Brazil." BMC Research Notes 8 (1). doi: 10.1186/s13104-015-1335-1.

da Silva Lacerda, Viviane, Juan B. López-Sotelo, Adriana Correa-Guimarães, Salvador Hernández-Navarro, Mercedes Sánchez-Báscones, Luis M. Navas-Gracia, Pablo Martín-Ramos, and Jesús Martín-Gil. 2015. "Rhodamine B removal with activated carbons obtained from lignocellulosic waste." Journal of Environmental Management 155 (0):67-76. doi: 10.1016/j.jenvman.2015.03.007.

da Silva Lacerda, Viviane, Juan Benito López-Sotelo, Adriana Correa-Guimarães, Salvador Hernández-Navarro, Mercedes Sánchez-Bascones, Luis M. NavasGracia, Pablo Martín-Ramos, Eduardo Pérez-Lebeña, and Jesús Martín-Gil. 2015. "A kinetic study on microwave-assisted conversion of cellulose and lignocellulosic waste into hydroxymethylfurfural/furfural." Bioresource Technology 180 (0):88-96. doi: 10.1016/j.biortech.2014.12.089.

da Silva, Willian, Acacia Salomão, Patricia de Souza, Marina Ansolin, and Matthieu Tubino. 2017. "Binary Blends of Biodiesel from Macauba (Acromia aculeata) Kernel Oil with Other Biodiesels." Journal of the Brazilian Chemical Society. doi: 10.21577/0103-5053.20170134.

De, Dipankar, R. S. Singh, and Hukum Chandra. 2001. "Technological impact on energy consumption in rainfed soybean cultivation in Madhya Pradesh." Applied Energy 70 (3):193-213. doi: 10.1016/s0306-2619(01)00035-6.

del Río, José C., Anderson B. Evaristo, Gisela Marques, Pablo Martín-Ramos, Jesús Martín-Gil, and Ana Gutiérrez. 2016. "Chemical composition and thermal 
behavior of the pulp and kernel oils from macauba palm (Acrocomia aculeata) fruit." Industrial Crops and Products 84:294-304. doi: 10.1016/j.indcrop.2016.02.018.

Delucchi, Mark A. 2010. "Impacts of biofuels on climate change, water use, and land use." Annals of the New York Academy of Sciences 1195 (1):28-45. doi: 10.1111/j.1749-6632.2010.05457.x.

Doering, O.C., T.J. Considine, and C.E. Harling. 1977. "Accounting for tillage equipment and other machinery in agricultural energy analysis." In, 4. West Lafayette, IN, USA: Agricultural Experiment Station, Purdue University.

Empresa de Pesquisa Energética. 2013. "Balanço Energético Nacional (BEN)." In. Rio de Janeiro, RJ, Brazil: Empresa de Pesquisa Energética (EPE).

European Committee for Standardization (CEN). 2006. "Solid biofuels - Determination of total content of carbon, hydrogen and nitrogen." In. Stockholm, Sweden: European Committee for Standardization (CEN).

Evaristo, Anderson Barbosa. 2015. "Conservação pós-colheita e potencial bioenergético de frutos de macaúba (Acrocomia aculeata)." Universidade Federal de Viçosa.

Evaristo, Anderson Barbosa, José Antonio Saraiva Grossi, Angélica de Cássia Oliveira Carneiro, Leonardo Duarte Pimentel, Sergio Yoshimitsu Motoike, and Kacilda Naomi Kuki. 2016. "Actual and putative potentials of macauba palm as feedstock for solid biofuel production from residues." Biomass and Bioenergy 85:18-24. doi: 10.1016/j.biombioe.2015.11.024.

Evaristo, Anderson Barbosa, José Antonio Saraiva Grossi, Leonardo Duarte Pimentel, Samuel de Melo Goulart, Adalvan Daniel Martins, Vera Lúcia dos Santos, and Sergio Motoike. 2016. "Harvest and post-harvest conditions influencing macauba 
(Acrocomia aculeata) oil quality attributes." Industrial Crops and Products 85:6373. doi: 10.1016/j.indcrop.2016.02.052.

Evaristo, Anderson Barbosa, Daniela Correia Martino, Adriano Henrique Ferrarez, Danilo Barros Donato, Angélica De Cássia Oliveira Carneiro, and José Antônio Saraiva Grossi. 2016. "Potencial EnergÉtico Dos ResÍduos Do Fruto Da MacaÚba E Sua UtilizaÇÃo Na ProduÇÃo De CarvÃo Vegetal." Ciência Florestal 26 (2):571. doi: 10.5902/1980509822757.

Falasca, Silvia, Ana Ulberich, and Sandra Pitta-Alvarez. 2016. "Development of agroclimatic zoning model to delimit the potential growing areas for macaw palm (Acrocomia aculeata)." Theoretical and Applied Climatology 129 (3-4):1321-33. doi: 10.1007/s00704-016-1850-6.

Fargione, J., J. Hill, D. Tilman, S. Polasky, and P. Hawthorne. 2008. "Land Clearing and the Biofuel Carbon Debt." Science 319 (5867):1235-8. doi: 10.1126/science.1152747.

Fazio, Simone, and Lorenzo Barbanti. 2014. "Energy and economic assessments of bioenergy systems based on annual and perennial crops for temperate and tropical areas." Renewable Energy 69:233-41. doi: 10.1016/j.renene.2014.03.045.

Fazio, Simone, and Andrea Monti. 2011. "Life cycle assessment of different bioenergy production systems including perennial and annual crops." Biomass and Bioenergy 35 (12):4868-78. doi: 10.1016/j.biombioe.2011.10.014.

Germer, J., and J. Sauerborn. 2007. "Estimation of the impact of oil palm plantation establishment on greenhouse gas balance." Environment, Development and Sustainability 10 (6):697-716. doi: 10.1007/s10668-006-9080-1.

Gomes Jr, Rui Alberto, Fabio de Lima Gurgel, Leonardo de Azevedo Peixoto, Leonardo Lopes Bhering, Raimundo Nonato Vieira da Cunha, Ricardo Lopes, Antônio José 
de Abreu Pina, and Alexandre Sanz Veiga. 2014. "Evaluation of interspecific hybrids of palm oil reveals great genetic variability and potential selection gain." Industrial Crops and Products 52:512-8. doi: 10.1016/j.indcrop.2013.10.036.

González-García, Sara, Daniel García-Rey, and Almudena Hospido. 2012. "Environmental life cycle assessment for rapeseed-derived biodiesel." The International Journal of Life Cycle Assessment 18 (1):61-76. doi: 10.1007/s11367-012-0444-5.

Hansen, Sune. 2005. "Feasibility Study of Performing an Life Cycle Assessment on Crude Palm Oil Production in Malaysia (9 pp)." The International Journal of Life Cycle Assessment 12 (1):50-8. doi: 10.1065/lca2005.08.226.

Henderson, Andrew, Gloria Galeano-Garces, and Rodrigo Bernal. 1997. Field guide to the palms of the Americas. Princeton, NJ, USA: Princeton University Press.

IBGE. 2006. "Censo agropecuário 2006: resultados preliminares." In. Rio de Janeiro, RJ, Brazil: Instituto Brasileiro de Geografia e Estatística.

Intergovernmental Panel on Climate Change (IPCC). 2006. "Agriculture, Forestry and Other Land Use." In IPCC Guidelines for national greenhouse gas inventories, edited by IPCC. Japan: Institute for Global Environmental Strategies.

International Energy Agency. 2016. World Energy Outlook 2016. Paris, France: International Energy Agency.

IPCC. 2014. "Climate Change 2014: Synthesis Report." In Fifth Assessment Report of the Intergovernmental Panel on Climate Change, 151. Geneva, Switzerland: IPCC.

ISO. 1995. ISO 10565:1998. Oilseeds. Simultaneous determination of oil and water contents. Method using pulsed nuclear magnetic resonance spectrometry. Geneva, Switzerland: International Organization for Standardization. 
ISO. 2015. ISO 18134-3:2015. Solid biofuels. Determination of moisture content. Oven dry method. Part 3: Moisture in general analysis sample. Geneva, Switzerland: International Organization for Standardization.

Kline, Keith L., Siwa Msangi, Virginia H. Dale, Jeremy Woods, Glaucia M Souza, Patricia Osseweijer, Joy S. Clancy, et al. 2017. "Reconciling food security and bioenergy: priorities for action." GCB Bioenergy 9 (3):557-76. doi: 10.1111/gcbb.12366.

Li, Xue, and Edmund Mupondwa. 2014. "Life cycle assessment of camelina oil derived biodiesel and jet fuel in the Canadian Prairies." Science of the Total Environment 481:17-26. doi: 10.1016/j.scitotenv.2014.02.003.

Lopes, Ricardo, Raimundo Nonato Vieira da Cunha, and Marcos Deon Vilela de Resende. 2012. "Produção de cachos e parâmetros genéticos de híbridos de caiaué com dendezeiro." Pesquisa Agropecuária Brasileira 47 (10):1496-503. doi: 10.1590/s0100-204x2012001000012.

Macedo, Isaias C., Joaquim E. A. Seabra, and João E. A. R. Silva. 2008. "Green house gases emissions in the production and use of ethanol from sugarcane in Brazil: The 2005/2006 averages and a prediction for 2020." Biomass and Bioenergy 32 (7):582-95. doi: 10.1016/j.biombioe.2007.12.006.

Manfio, Candida Elisa, Sérgio Yoshimitsu Motoike, Carlos Eduardo Magalhães dos Santos, Leonardo Duarte Pimentel, Vanessa de Queiroz, and Aurora Yoshiko Sato. 2011. "Repetibilidade em características biométricas do fruto de macaúba." Ciência Rural 41 (1):70-6. doi: 10.1590/s0103-84782011000100012.

Ministério do Meio Ambiente. 2011. "1º Inventário Nacional de Emissões Atmosféricas por Veículos Automotores Rodoviários - Relatório Final." In, 114. Brazil: 
Ministério do Meio Ambiente, Secretaria de Mudanças Climáticas e Qualidade Ambiental.

Monti, Andrea, Simone Fazio, and Gianpietro Venturi. 2009. "Cradle-to-farm gate life cycle assessment in perennial energy crops." European Journal of Agronomy 31 (2):77-84. doi: 10.1016/j.eja.2009.04.001.

Montoya, Sebastián Giraldo, Sérgio Yoshimitsu Motoike, Kacilda Naomi Kuki, and Adriano Donato Couto. 2016. "Fruit development, growth, and stored reserves in macauba palm (Acrocomia aculeata), an alternative bioenergy crop." Planta 244 (4):927-38. doi: 10.1007/s00425-016-2558-7.

Motoike, S. Y., M. Carvalho, L. D. Pimentel, K. N. Kuki, J. M. V. Paes, H. C. T. Dias, and A. Y. A. Sato. 2013. A cultura da Macaúba: Implantação e manejo de cultivos racionais. Vol. 1. Viçosa, Brazil: Editora UFV.

Motoike, SY, and KN Kuki. 2009. "The potential of macaw palm (Acrocomia aculeata) as source of biodiesel in Brazil." International Review of Chemical Engineering $1(6): 632-5$.

Nunes, Angela A., Simone P. Favaro, Fabio Galvani, and Cesar H. B. Miranda. 2015. "Good practices of harvest and processing provide high quality Macauba pulp oil." European Journal of Lipid Science and Technology 117 (12):2036-43. doi: 10.1002/ejlt.201400577.

Pimentel, David. 1980. Handbook of energy utilization in agriculture. Boca Raton, FL, USA: CRC Press, Inc.

Pimentel, L., C. Manfio, S. Motoike, J. Paes, and C. Bruckner. 2011a. "Coeficientes técnicos e custos de produção do cultivo da macaúba." In Macaúba: potencial e sustentabilidade para o biodiesel, 20-30. Belo Horizonte, MG, Brazil: Epamig. 
Pimentel, L., C. Manfio, S. Motoike, J. Paes, and C. Bruckner. 2011b. "Recomendação de adubação e calagem para o cultivo da macaúba: $1^{0}$ aproximação." Informe Agropecuário 32:30-8.

Pires, Thiago Pereira, Elma dos Santos Souza, Kacilda Naomi Kuki, and Sérgio Yoshimitsu Motoike. 2013. "Ecophysiological traits of the macaw palm: A contribution towards the domestication of a novel oil crop." Industrial Crops and Products 44:200-10. doi: 10.1016/j.indcrop.2012.09.029.

Plath, Mirco, Christine Moser, Rob Bailis, Patric Brandt, Heidi Hirsch, Alexandra-Maria Klein, David Walmsley, and Henrik von Wehrden. 2016. "A novel bioenergy feedstock in Latin America? Cultivation potential of Acrocomia aculeata under current and future climate conditions." Biomass and Bioenergy 91:186-95. doi: 10.1016/j.biombioe.2016.04.009.

Pulles, Tinus. 2017. "Engineering photosynthesis: a necessary tool to protect the world's climate?" Carbon Management 8 (2):167-73. doi: 10.1080/17583004.2017.1309201.

Ramadhas, A. S., S. Jayaraj, and C. Muraleedharan. 2004. "Use of vegetable oils as I.C. engine fuels-A review." Renewable Energy 29 (5):727-42. doi: 10.1016/j.renene.2003.09.008.

Ramos, A.M., L.A.R. Dos Santos, and L.T.G. Fortes. 2009. Normais climatológicas do Brasil 1961-1990: edição revista e ampliada. Brazil: Instituto Nacional de Meteorologia (INMET).

Refsgaard, Karen, Niels Halberg, and Erik Steen Kristensen. 1998. "Energy utilization in crop and dairy production in organic and conventional livestock production systems." Agricultural Systems 57 (4):599-630. doi: 10.1016/s0308$521 x(98) 00004-3$. 
Reis, Sarah Barbosa, Maria Olívia Mercadante-Simões, and Leonardo Monteiro Ribeiro. 2012. "Pericarp development in the macaw palm Acrocomia aculeata (Arecaceae)." Rodriguésia 63 (3):541-9. doi: 10.1590/s217578602012000300005

Scariot, Aldicir, Eduardo Lleras, and John D. Hay. 1995. "Flowering and Fruiting Phenologies of the Palm Acrocomia aculeata: Patterns and Consequences." Biotropica 27 (2):168. doi: 10.2307/2388992.

Scariot, Aldicir O., Eduardo Lleras, and John D. Hay. 1991. "Reproductive Biology of the Palm Acrocomia aculeata in Central Brazil." Biotropica 23 (1):12. doi: $10.2307 / 2388683$.

Shonnard, David R., Bethany Klemetsrud, Julio Sacramento-Rivero, Freddy NavarroPineda, Jorge Hilbert, Robert Handler, Nydia Suppen, and Richard P. Donovan. 2015. "A review of environmental life cycle assessments of liquid transportation biofuels in the Pan American region." Environmental Management 56 (6):135676. doi: 10.1007/s00267-015-0543-8.

Silva, J.C. 2007. Macaúba: fonte de matéria-prima para os setores alimentício, energético e industrial. Viçosa, Brazil: UFV.

Tolêdo, Diego de Paula. 2010. "Análise técnica, econômica e ambiental de macaúba e de pinhão-manso como alternativas de agregação de renda na cadeia produtiva de biodiesel." Universidade Federal de Viçosa.

Tomei, Julia, and Richard Helliwell. 2016. "Food versus fuel? Going beyond biofuels." Land Use Policy 56:320-6. doi: 10.1016/j.landusepol.2015.11.015.

U.S. Energy Information Administration. 2017. "International Energy Outlook 2017." In, 76. Washington D.C., USA. 
UNFCCC. 2010. "ACM0017: Production of biodiesel for use as fuel (v.2.1.0)." In. New York, NY, USA: United Nations Framework Convention on Climate Change.

Vianna, Fernanda Cristina. 2006. "Análise de ecoeficiência: avaliação do desempenho econômico-ambiental do biodiesel e petrodiesel." Universidade de São Paulo.

Vilas Boas, M.A., A.C.O. Carneiro, B.R. Vital, A.M.M.L. Carvalho, and M.A. Martins. 2010. "Efeito da temperatura de carbonização e dos resíduos de macaúba na produção de carvão vegetal." Scientia Forestalis, Piracicaba 38 (87):481-90.

Yaldiz, O, HH Ozturk, Y Zeren, and A Bascetincelik. 1993. Energy usage in production of field crops in Turkey. Paper presented at the 5th International Congress on Mechanisation and Energy Use in Agriculture, Kusadasi, Turkey. 
Table 1. Agricultural inputs consumption, agricultural machinery and manual labor required for macauba palm cultivation over a 30-year period. Values per year are shown in brackets.

\begin{tabular}{|c|c|c|c|c|c|c|}
\hline \multirow{2}{*}{ Activities } & \multirow{2}{*}{ Units } & \multicolumn{4}{|l|}{ Years } & \multirow{2}{*}{ Total } \\
\hline & & $0-1$ & $2-5$ & $6-9$ & $10-30$ & \\
\hline \multicolumn{7}{|c|}{ Land preparation and maintenance } \\
\hline \multirow[t]{2}{*}{ Machinery and implements } & $h \cdot h a^{-1}$ & 5.39 & 1.80 & 2.08 & 11.00 & 20.27 \\
\hline & $\mathrm{h} \cdot \mathrm{ha}^{-1} \cdot$ year $^{-1}$ & 5.39 & 0.45 & 0.52 & 0.55 & \\
\hline \multirow[t]{2}{*}{ Manual labor } & $\mathrm{h} \cdot \mathrm{ha}^{-1}$ & 13.39 & 1.64 & 2.04 & 11.20 & 28.27 \\
\hline & $\mathrm{h} \cdot \mathrm{ha}^{-1} \cdot$ year $^{-1}$ & 13.39 & 0.41 & 0.45 & 0.56 & \\
\hline \multicolumn{7}{|l|}{ Plantation } \\
\hline Machinery and implements & $h \cdot h a^{-1}$ & 3.00 & - & - & - & 3 \\
\hline Macauba cuttings & - & $475^{\dagger}$ & - & - & - & 475 \\
\hline Manual labor & $\mathrm{h} \cdot \mathrm{ha}^{-1}$ & 30.95 & - & - & - & 30.95 \\
\hline \multicolumn{7}{|l|}{ Crop management } \\
\hline \multirow[t]{2}{*}{ Machinery and implements } & $\mathrm{h} \cdot \mathrm{ha}^{-1}$ & 3.83 & 10.08 & 13.60 & 77.70 & 105.21 \\
\hline & $\mathrm{h} \cdot \mathrm{ha}^{-1} \cdot$ year $^{-1}$ & 3.83 & 2.52 & 3.40 & 3.70 & \\
\hline \multirow[t]{2}{*}{ Manual labor } & $\mathrm{h} \cdot \mathrm{ha}^{-1}$ & 14.83 & 69.33 & 73.92 & 389.13 & 574.21 \\
\hline & h.ha'-1. year ${ }^{-1}$ & 14.83 & 17.33 & 18.48 & 18.53 & \\
\hline \multirow[t]{2}{*}{ Lime } & $\mathrm{t} \cdot \mathrm{ha}^{-1}$ & 4.00 & 2.00 & 3.00 & 21.00 & 30 \\
\hline & $\mathrm{t} \cdot \mathrm{ha}^{-1} \cdot$ year $^{-1}$ & 4.00 & 0.50 & 0.75 & 1.05 & \\
\hline \multirow[t]{2}{*}{ Fertilizers } & $\mathrm{t} \cdot \mathrm{ha}^{-1}$ & 0.37 & 2.52 & 6.17 & 44.03 & 53.09 \\
\hline & $\mathrm{t} \cdot \mathrm{ha}^{-1} \cdot$ year $^{-1}$ & 0.37 & 0.63 & 1.54 & 2.10 & \\
\hline \multirow[t]{2}{*}{ Agrochemicals } & $\mathrm{kg} \cdot \mathrm{ha}^{-1}$ & 10.00 & 13.52 & 8.72 & 45.78 & 78.02 \\
\hline & $\mathrm{kg} \cdot \mathrm{ha}^{-1} \cdot$ year $^{-1}$ & 10.00 & 3.38 & 2.18 & 2.18 & \\
\hline \multicolumn{7}{|l|}{ Harvesting ${ }^{\ddagger}$} \\
\hline \multirow[t]{2}{*}{ Machinery and implements } & $h \cdot h a^{-1}$ & & 4.10 & 28.37 & 175.6 & 208.07 \\
\hline & $h \cdot h^{-1} \cdot$ year $^{-1}$ & 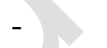 & 1.02 & 7.09 & 8.36 & \\
\hline \multirow[t]{2}{*}{ Manual labor } & $\mathrm{h} \cdot \mathrm{ha}^{-1}$ & - & 75.2 & 520.35 & 3220.75 & 3816.3 \\
\hline & $h \cdot h^{-1} \cdot$ year $^{-1}$ & - & 18.8 & 130.09 & 153.37 & \\
\hline
\end{tabular}

† 461 rooted plants +14 plants for replanting

* Transport to process plant not included

Table 2. Scenarios for the production of macauba palm fresh bunches based on the plant selection index.

\begin{tabular}{|c|c|c|c|}
\hline \multirow{2}{*}{ Parameters } & \multicolumn{3}{|l|}{ Scenarios } \\
\hline & S1 & $\mathrm{S} 2$ & S3 \\
\hline Selection index $^{\dagger}$ & Population average & $50 \%$ & $30 \%$ \\
\hline Number of bunches per plant & 2.36 & 3.48 & 4.08 \\
\hline Fruit production per plant $(\mathrm{kg})^{\ddagger}$ & 57.87 & 85.33 & 100.04 \\
\hline EFB weight (kg) & 1.17 & 1.17 & 1.17 \\
\hline
\end{tabular}

${ }^{\dagger}$ Selection index based on the evaluation of the number of bunches for 100 macauba palm native adult plants: $50 \%$ and $30 \%$ of the plants with the highest number of bunches. ${ }^{\ddagger}$ Fruit production per plant $=$ number of bunches per plant $\times$ $24.52 \mathrm{~kg}$ fruit/bunch (average fruit production), considering plants older than 10 years. 
Table 3. Equivalent energy of the inputs required for macauba palm cultivation.

\begin{tabular}{llll}
\hline Energy resource & Units & Equivalence in MJ & Reference \\
\hline Fuel & $\mathrm{kg}$ & 42 & (Empresa de Pesquisa Energética 2013) \\
Greases & $\mathrm{kg}$ & 39 & (Empresa de Pesquisa Energética 2013) \\
Lubricants & $\mathrm{kg}$ & 40.2 & (Empresa de Pesquisa Energética 2013) \\
Cuttings production & $\mathrm{ha}$ & 176.63 & This work \\
Lime & $\mathrm{t}$ & 30 & (Refsgaard et al. 1998) \\
Nitrogen & $\mathrm{kg}$ & 60.6 & (De et al. 2001) \\
Phosphorus & $\mathrm{kg}$ & 11.1 & (De et al. 2001) \\
Potassium & $\mathrm{kg}$ & 6.7 & (De et al. 2001) \\
Insecticides & $\mathrm{kg}$ & 152 & (Pimentel 1980) \\
Herbicides & $\mathrm{L}$ & 331.65 & (Pimentel 1980) \\
Machinery manufacturing & $\mathrm{kg}$ & 14.62 & (Doering et al. 1977) \\
Tires production & $\mathrm{kg}$ & 85.83 & (Doering et al. 1977) \\
Manual labor & $\mathrm{h}$ & 2.3 & (Yaldiz et al. 1993) \\
\hline
\end{tabular}

Table 4. Evolution of the productivity of fresh bunch $\left(\mathrm{Mg} \mathrm{ha}^{-1}\right)$ for macauba palm over a 30-year cultivation period and production of dry matter (DM), carbon (C) and oil from the constituent parts of the bunch.

\begin{tabular}{|c|c|c|c|c|c|c|}
\hline \multirow{2}{*}{ Scenarios } & \multicolumn{6}{|l|}{ Years ${ }^{\ddagger}$} \\
\hline & 5 & 6 & 7 & 8 & 9 & $>10$ \\
\hline S1 & 9.8 & 14.1 & 18.3 & 21.0 & 24.5 & 27.9 \\
\hline S2 & 14.5 & 20.9 & 27.0 & 30.9 & 36.1 & 41.2 \\
\hline S3 & 17.0 & 24.5 & 31.7 & 36.2 & 42.3 & 48.3 \\
\hline \multicolumn{2}{|c|}{ Bunch constituents } & DM (kg) & \multicolumn{2}{|c|}{$\mathrm{C}(\%) \quad$ Oil $\left(\mathrm{g}^{\prime} \cdot \mathrm{g}^{-1}\right)$} & & \\
\hline \multirow{4}{*}{ Fruit } & Husk & 259.83 & 47.2 & - & & \\
\hline & Pulp & 446.27 & 43.8 & 0.45 & & \\
\hline & Endocarp & 196.59 & 48,0 & - & & \\
\hline & Almond & 51.92 & 45,0 & 0.62 & & \\
\hline \multicolumn{2}{|c|}{ Empty fruit bunch } & 45.40 & 45.9 & - & & \\
\hline \multicolumn{2}{|c|}{ Total Bunch (kg) } & 1000 & 456.9 & 235.3 & & \\
\hline
\end{tabular}

* The evolution of productivity is based on the increase of bunch productivity over the years, taking oil palm as a reference (Corley and Tinker 2015).

Table 5. Cumulative energy demand (CED), net energy (NE) and energy efficiency (EE) for the three proposed macauba palm cultivation scenarios. Those of other energy crops used in the tropics are provided for comparison purposes.

\begin{tabular}{lllll}
\hline Crop & CED $\left(\mathrm{GJ} \cdot \mathrm{ha}^{-1} \cdot \mathrm{yr}^{-1}\right)$ & $\mathrm{NE}\left(\mathrm{GJ} \cdot \mathrm{ha}^{-1} \cdot \mathrm{yr}^{-1}\right)$ & $\mathrm{EE}\left(\mathrm{GJ} \cdot \mathrm{GJ}^{-1}\right)$ & Reference \\
\hline Macauba - S1 & 21.9 & 287.2 & 14.1 & This work \\
Macauba - S2 & 22.0 & 433.8 & 20.7 & This work \\
Macauba - S3 & 22.1 & 512.3 & 24.2 & This work \\
Coconut palm & 8.2 & 213 & 13.1 & (Fazio and Barbanti 2014) \\
Oil palm & 12.1 & 571 & 25.1 & (Fazio and Barbanti 2014) \\
Jatropha & 5.9 & 130 & 16.7 & (Fazio and Barbanti 2014) \\
Castor bean & 8.6 & 108 & 10.5 & (Fazio and Barbanti 2014) \\
Sugar cane ${ }^{\ddagger}$ & 20.7 & 577 & 28.9 & (Fazio and Barbanti 2014) \\
Maize & 28.2 & 141 & 6.6 & (Fazio and Barbanti 2014) \\
Sunflower & 18 & 141 & 7.8 & (Fazio and Barbanti 2014) \\
\hline
\end{tabular}

\footnotetext{
${ }^{\ddagger}$ Lignocellulosic waste materials have been considered for sugar cane.
} 
Figure 1. System limits for the functional unit under study.

Figure 2. (a) Total fruit weight per bunch; (b) histogram of the number of fruit bunches per native macauba palm tree.

Figure 3. Estimated energy balance in 30 years of macauba palm cultivation for different productivity scenarios. Annual average values for $(a)$ energy input and $(b)$ output.

Figure 4. Estimate of GHG and $\mathrm{CO}_{2} \mathrm{eq}$ emissions over 30 years of macauba palm cultivation in the different scenarios of bunch productivity. 